Acta vet. scand. $1986,27,388-396$.

From the Norwegian College of Veterinary Medicine, Oslo and the National Veterinary Institute, Oslo, Norway.

\title{
BARIUM SELENATE AS A SLOW-RELEASE SELENIUM PREPARATION TO PIGS
}

\author{
By \\ Edgar Brun and Gunnar Øvernes
}

\begin{abstract}
BRUN, EDGAR and GUNNAR ØVERNES: Barium selenate as a slow-release selenium preparation to pigs. Acta vet. scand. 1986, 27, 388-396. - Pregnant sows were injected subcutaneously (s.c.) or intramuscularly (i.m.) with a barium selenate suspension (0.5-1.0 $\mathrm{mg} \mathrm{Se} / \mathrm{kg}$ body weight (b.w.)) and together with control animals fed a commercial diet. No response to the injection was seen either in blood selenium levels or in glutathione peroxidase (GSH-Px) activity in the sows. There was, however, a significant difference in these parameters between piglets born from treated dams and control animals. This status was maintained during the nursing period. In another experiment pigs $(20 \mathrm{~kg} \mathrm{b.w.)}$ on a Se-deficient diet were injected s.c. and i.m. with barium selenate $(2.5 \mathrm{mg} \mathrm{Se} / \mathrm{kg}$ b.w.). The treated groups maintained their blood levels of selenium and GSH-Px activity, although the selenium values in the group treated intramuscularly started to decline after 4 weeks. Organ samples from both groups were equal with regard to selenium at the time of slaughter while the control group showed a rapid decline both in blood selenium levels and GHS-Px activity.
\end{abstract}

s ows; piglets; depot; long acting; selenium deficien cy.

A depot preparation of barium selenate has recently been developed. Barium selenate has a very low solubility, and after injection of a viscous suspension the depot will slowly release selenium (Cawley, pers. comm.). So far, this has primarily been given to sheep and cattle to prevent selenium deficiency in the animal itself and in its offspring (MacPherson \& Chalmers 1984, Cawley \& McPhee 1984, Øvernes et al. 1985). The recommended dosage for the prevention and treatment of selenium deficiency in cattle and sheep is $1 \mathrm{ml}$ subcutaneously per $50 \mathrm{~kg}$ bodyweight ( $1 \mathrm{mg} \mathrm{Se} / \mathrm{kg} \mathrm{b.w.).} \mathrm{In} \mathrm{ewes} \mathrm{this} \mathrm{treatment} \mathrm{has} \mathrm{improved} \mathrm{the}$ blood levels of Se and GSH-Px activity, reaching a peak after 6 weeks (Anon. 1982). 
Experiments were carried out to test the effect of barium selenate on blood selenium and GSH-Px activity in pregnant sows, their offspring and in feeder pigs.

\section{MATERIAL AND METHODS}

Experiment I: Fourteen pregnant pluriparous sows of Norwegian landrace were divided into 4 groups. Barium selenate as Deposel ${ }^{\circledR}{ }^{1}$ was injected into the thirty-days pregnant sows in the following ways: Group 1: $100 \mathrm{mg}$ Se s.c., Group 2: $100 \mathrm{mg}$ Se i.m., Group 3: $200 \mathrm{mg}$ Se i.m., Group 4: Control animals. Blood samples were taken at day 30 (before the injection of Deposel $(\circledR)$ and later at day 70 and day 110 of gestation. Before and during the experiment the sows were fed a commercial diet adequate in Se $(0.35 \mathrm{mg} \mathrm{Se} / \mathrm{kg}$ feed $)$ and vitamin $\mathrm{E}(56 \mathrm{mg}$ alpha-tocopherol $/ \mathrm{kg}$ feed). One week after delivery blood samples were drawn from 4 randomly picked piglets of every litter. Blood samples from these piglets were again drawn 3 and 5 weeks post partum.

Exp e r i m e $n$ I I: Eight Norwegian landrace pigs of approximately $20 \mathrm{~kg}$ b.w. were divided into 3 groups. Three pigs were injected strictly s.c. with $50 \mathrm{mg}$ Se as Deposel ${ }^{\circledR}$ and 3 were injected i.m. with the same amount of Se. Two pigs served as control. After injection the pigs were immediately put on a Sedeficient diet, consisting of casein powder together with a mixture of barley and oats. The casein fraction was kept at a constant level $(0.1 \mathrm{~kg} /$ animal and day), whereas the grain mixture was increased from $1.2 \mathrm{~kg}$ to $2.2 \mathrm{~kg}$ per animal and day. The diet was supplemented with the vitamin A, D and $E$ together with dicalcium phosphate. Total Se and alpha-tocopherol content of the diet were $0.05 \mathrm{mg}$ and $50 \mathrm{mg} / \mathrm{kg}$ feed, respectively. The experiment lasted for 8 weeks and the pigs were slaughtered at the weight of $50-60 \mathrm{~kg}$. Blood samples were drawn at the beginning of the period and later every second week. In both experiments selenium status in whole blood and organs was determined by a hydride generation method (Norheim \& Haugen 1985). GSH-Px activity in whole blood was determined as described by Paglia \& Valentine (1967). Statistical calculations were performed by using an F-test and a correlation program according to Nissen (1982).

${ }^{1}$ Deposel@, $50 \mathrm{mg} \mathrm{Se} / \mathrm{ml}$, Rycovet Ltd., Glasgow, Scotland. 


\section{RESULTS}

Experiment $I$ : There were no significant differences in blood selenium or GSH-Px activity between the sows in the different groups (Table 1).

T a ble 1. Selenium levels $(\mu \mathrm{g} / \mathrm{ml})$ and GSH-Px activities ( $\mu \mathrm{kat} / \mathrm{l}$ ) at 30,70 and 110 days of gestation in blood from sows injected with depot barium selenate. Group 1: $100 \mathrm{mg}$ Se s.c., Group 2: $100 \mathrm{mg}$ Se i.m., Group 3: $200 \mathrm{mg}$ Se i.m., Group 4: Control.

\begin{tabular}{|c|c|c|c|c|}
\hline Group & $\mathbf{n}$ & 30 days $(\mathrm{SD})$ & 70 days $(S D)$ & 110 days $(\mathrm{SD})$ \\
\hline \multicolumn{5}{|c|}{ Selenium } \\
\hline 1 & $\mathbf{3}$ & $0.28 \quad(0.03)$ & $0.26 \quad(0.01)$ & not analysed \\
\hline 2 & 3 & $0.27 \quad(0.03)$ & $0.24 \quad(0.01)$ & $0.25 \quad(0.03)$ \\
\hline 3 & 4 & $0.24 \quad(0.02)$ & $0.24 \quad(0.02)$ & $0.22 \quad(0.04)$ \\
\hline 4 & 4 & $0.24 \quad(0.02)$ & $0.25 \quad(0.01)$ & $0.20 \quad(0.02)$ \\
\hline \multicolumn{5}{|c|}{$G S H-P x$} \\
\hline 1 & $\mathbf{3}$ & $168(56)$ & $169 \quad(40)$ & not analysed \\
\hline 2 & $\mathbf{3}$ & $196(73)$ & $284 \quad(89)$ & 242 (118) \\
\hline 3 & 4 & $189 \quad(45)$ & $221 \quad(49)$ & $237 \quad(95)$ \\
\hline 4 & 4 & $156 \quad(41)$ & $186 \quad(34)$ & $156 \quad(36)$ \\
\hline
\end{tabular}

n: number of sows

SD: standard deviation

Blood selenium levels and GSH-Px activity were significantly lower in piglets born from the control animals than from the treated groups (Table 2). The difference in blood selenium was greatest the first week post partum, but a significant difference was maintained throughout the experimental period. The difference in GSH-Px activity increased from the first to the third week and remained at a significantly higher level throughout the experimental period. Differences between the treated groups were not detected.

The correlation between selenium blood levels and GSH-Px activity was $r=0.47$ for the sows and $r=0.70$ for the piglets.

Experiment I I: After 2 weeks the mean blood selenium levels in the s.c. and i.m. groups rose from 0.11 and $0.12 \mu \mathrm{g} / \mathrm{ml}$ to $0.17 \mu \mathrm{g} / \mathrm{ml}$. The mean Se value for pigs in the s.c. group remained at a stable level while the i.m. group continued to rise and reached a peak $(0.19 \mu \mathrm{g} / \mathrm{ml}) 4$ weeks after the injection and declined thereafter. At the end of the experiment the mean blood selenium value was $0.17 \mu \mathrm{g} / \mathrm{ml}$ for the s.c. group and $0.12 \mu \mathrm{g} / \mathrm{ml}$ 
T able 2. Blood selenium levels $(\mu \mathrm{g} / \mathrm{ml})$ and GSH-Px activities ( $\mu$ kat/1) in piglets 1,3 and 5 weeks post partum, from sows supplemented with depot barium selenate: Group 2: $100 \mathrm{mg}$ Se i.m., Group 3: $200 \mathrm{mg}$ Se i.m. and from nonsupplemented dams (Group 4).

\begin{tabular}{|c|c|c|c|c|}
\hline Group & $\mathbf{n}$ & 1 week (SD) & 3 weeks $(\mathrm{SD})$ & 5 weeks $(\mathrm{SD})$ \\
\hline \multicolumn{5}{|c|}{ Selenium } \\
\hline 2 & 11 & $0.13(0.02)^{\star \star}$ & $0.13(0.01)^{*}$ & $0.15(0.02)^{*}$ \\
\hline 3 & 16 & $0.12(0.02)^{\star \star}$ & $0.12(0.01)^{*}$ & $0.13(0.01)^{\star}$ \\
\hline 4 & 16 & $0.09(0.01)$ & $0.10(0.02)$ & $0.12(0.02)$ \\
\hline \multicolumn{5}{|c|}{$G S H-P x$} \\
\hline 2 & 11 & $110(23)^{*}$ & $123(16)^{\star \star}$ & $140(22)^{\star *}$ \\
\hline 3 & 16 & $108(31)^{\star}$ & $123(23)^{\star \star}$ & $137(36)^{* *}$ \\
\hline 4 & 16 & $77(39)$ & $91(28)$ & $93(28)$ \\
\hline
\end{tabular}

$\mathrm{n}$ : number of piglets

SD: standard deviation

* $\quad P<0.05$

$\star * \quad \mathrm{P}<0.005$

for the i.m. group. Individual pigs had a different selenium response to the injection, but the various pigs followed the tendency of their group (Fig. 1). GSH-Px activity in the 2 treat-

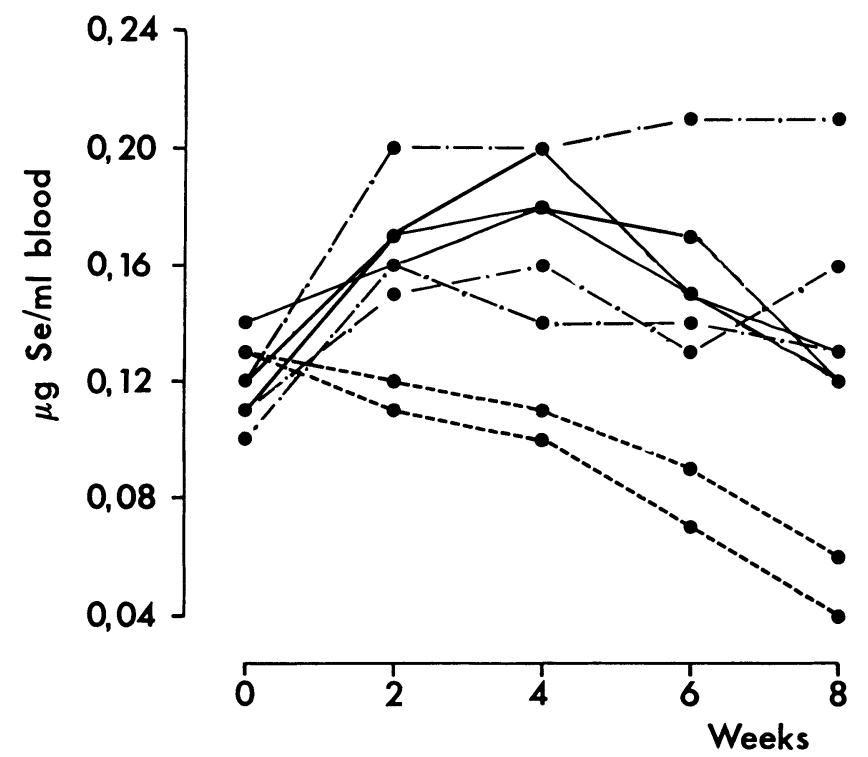

Figure 1. Effect on blood selenium after one single subcutaneous (-._.—.) or intramuscular (— selenate (Deposelß) in feeder pigs $(20 \mathrm{~kg} \mathrm{b.w.)}$ - _ _ C Control animals. 
ment groups remained almost constant, although at different levels during the experiment. Mean values for the s.c. and i.m. groups were 200 and $160 \mu \mathrm{kat} / \mathrm{l}$ respectively. The pigs in the control group promptly started to decline in blood selenium (Fig. 1) and reached a mean value of $0.08 \mu \mathrm{g} / \mathrm{ml}$ after 6 weeks. GSH-Px activity declined in accordance to the decreasing Se status and reached a mean value of $99 \mu \mathrm{kat} / \mathrm{l}$ and $80 \mu \mathrm{kat} / \mathrm{l}$ after 6 and 8 weeks respectively.

Selenium levels in organs were determined after slaughter (Table 3). The liver levels were equal in the treatment groups. Kidneys from the i.m. group contained more selenium than those from the s.c. group. The correlation between blood Se and GSH$P x$ activity in the i.m. group was $r=0.06$. For the s.c. and the control groups the correlation was $r=0.70$ and $r=0.90$ respectively.

Table 3. Mean selenium levels ( $\mu$ g Se/g w.w.) at slaughter in liver and kidneys from pigs injected subcutaneously (S.c. group) and intramuscularly (I. m. group) with $50 \mathrm{mg}$ Se as barium and from control animals.

\begin{tabular}{lcc}
\hline & Liver (SD) & Kidney (SD) \\
\hline S.c. group & $0.51(0.12)$ & $2.1(0.30)$ \\
I.m. group & $0.51(0.04)$ & $2.5(0.20)$ \\
Control & $0.13(0.00)$ & $1.3(0.10)$ \\
\hline
\end{tabular}

SD: standard deviation

\section{DISCUSSION}

The treated groups in Experiment II responded well to the depot preparation of barium selenate. However, a clear difference was seen between the mode of application with regard to the utilization of the released selenium. The s.c. injection of depot barium selenate gave a higher correlation between blood selenium and GSH-Px activity than the i.m. injection. This indicated a better utilization of the s.c. administered selenium. GSH-Px activity has earlier been used as a direct parameter for selenium status in swine (Sivertsen et al. 1977). In spite of the high blood levels of selenium after four weeks in the i.m. group there was no reflection in increased GSH-Px activity. The i.m. depot probably released its Se content too quickly for incorporation into GSH-Px. 
The ability to store Se in body tissue seemed not to be affected by the mode of application, as demonstrated by the levels of selenium in liver and kidney tissues. Concentrations of Se in liver were in agreement with earlier findings in Norwegian slaughter pigs (Frøslie et al. 1985).

The control animals declined very fast in both blood selenium and GSH-Px activity. Thus a period of less than 6 weeks on the selenium deficient diet brought this group under the critical level of $0.10 \mu \mathrm{g} \mathrm{Se} / \mathrm{ml}$ blood (McMurray \& Rice 1982).

Low liver values of Se at slaughter were consistent with the low blood values seen during the prolonged Se-deficiency. This rapid depletion of selenium is of practical importance as selenium deficiency disorders among pigs are most frequently seen during the fast growing period from 20 to $60 \mathrm{~kg}$ b.w. Selenium status has been shown to affect the immune system of growing pigs (Larsen \& Tollersrud 1981, Peplowski et al. 1981) and influence the susceptibility to swine dysentery (Teige et al. 1982). The present findings indicate that feeder pigs very quickly can be brought into a state of deficiency with an increased risk of illness.

The depot of barium selenate in Experiment I may have increased the Se-content in the milk. This may be one explanation for the higher levels of Se and GSH-Px activity in blood from piglets from Se supplemented than from unsupplemented dams. The situation was maintained throughout the suckling period. This is in agreement with Grifo \& Moxon (1973) who showed that selenium supplement to pregnant sows improved the Se status of the milk. Rasmussen (1974) has shown that colostrum is rich in selenium.

This is, however, not the only possible explanation for the differences between treated and untreated animals. The depot supply may also have increased the rate of selenium transport across the placenta, improving the selenium status of the fetuses. This explanation may be supported by the fact that the highest level of significance was found 1 week post partum.

Whether an increased supply of selenium in the fetal and suckling period can influence the activity of the immune system and decrease the mortality rate of piglets, is unknown. Friendship et al. (1984) found a positive and significant correlation between the selenium concentration in the diet of pregnant sows and the number of pigs weaned per sow per year. 
The good correlation between blood selenium and GSH-Px activity for the piglets is in agreement with observations by Sivertsen et al. (1977). For the sows, the selenium levels were higher than in the piglets and the correlation was lower. This supports an earlier observation that the correlation between these two parameters declines as blood selenium levels increase towards $0.25-0.30 \mu \mathrm{g} \mathrm{Se} / \mathrm{ml}$ (Brun, unpublished). This indicates that corresponding GSH-Px activity in pigs should only be used as mean values for screening the Se status in herds. This is also a conclusion drawn by Friendship et al. (1984).

For the sows in Experiment I, there was not registered any response in blood levels of selenium or GSH-Px activity after the barium selenate injection. An early rise in Se status might have been discovered by more frequent blood sampling during the first six weeks of the experiment. The lack of response may also be due to an insufficient dosage of selenium to animals with already high selenium status.

Under ordinary feeding conditions selenium supplementation should be given as a feed additive. Injections are neither the most physiological nor the most economic way of selenium administration. Depot preparation of barium selenate $(2.5 \mathrm{mg}$ $\mathrm{Se} / \mathrm{kg}$ b.w.) seems, however, to be a safe method to keep selenium at an adequate blood level during the most rapid growing period of feeder pigs kept on a very low selenium diet. This is in agreement with results obtained earlier with sheep and cattle (MacPehrson \& Chalmers 1984, Cawley \& McPhee 1984, Øvernes et al. 1985). In sows already adequate in selenium, an injection of $100-200 \mathrm{mg} \mathrm{Se} / \mathrm{sow}$ may still increase the Se content in the newborn. The injections should be given subcutaneously.

\section{ACKNOWLEDGEMENTS}

Deposel ${ }^{\circledR}$ was placed at our disposal by Rycovet, Glasgow, Scotland. This study was financially supported by the Norwegian Agricultural Research Council. We want to thank the Agricultural University of Norway for supplying the pigs and Keren Bar-Yaacov for correcting the English text. 


\section{REFERENCES}

Anonymous: Deposel long-acting injection. Product Information, Rycovet Ltd. 1982, 7 pp.

Cawley, G. D. \& J. McPhee: Trials with a long acting parenteral selenium preparation in ruminants: Sheep. Vet. Rec. 1984, 115, $565-566$.

Friendship, R. M., A. Butler, R. Hacker, I. McMillan, R. Pieper, S. S. Swaminathan \& M. R. Wilson: The relationship between blood glutathione peroxidase, feed selenium levels, age and mortality in pigs. Proc. 8th I.P.V.S. congress, Ghent, Belgium 1984, p. 331.

Frøslie, A., K. Moksnes \& G. Øvernes: The effect of selenium supplementation of animal feeds in Norway. Acta Agric. Scand. 1985, $35,139-144$.

Grifo, A.P.\& A. L. Moxon: Fishmeal as a source of selenium in sows. J. Anim. Sci. 1973, 37, 280, abstr. 203.

Larsen, H. J. \& S. Tollersrud: Effect of dietary vitamin E and selenium on the phytohaemagglutinin response of pig lymphocytes. Res. Vet. Sci. 1981, 31, 301-305.

MacPherson, A. \& J. S. Chalmers: Methods of selenium supplementation of ruminants. Vet. Rec. $1984,115,544-546$.

McMurray, C. H. \& D. A. Rice: Vitamin E and selenium deficiency diseases. Irish Vet. J. 1982, 36, 57-67.

Nissen, Ø.: Statistikkprogram for CP/M-maskinen. (Statistical programme for CP/M machines). Agricultural University of Norway. Dep. of Crop Science. Report No. 202. Ås 1982. 55 p.

Norheim, G. \& A. Haugen: Precise determination of selenium in human tissue using automated wet digestion and an automated hydride generator - atomic absorption spectroscopy system. In: Metabolism of trace elements related to human diseases. Nordic Symposium, Loen, Norway. Abstracts Oslo 1985, poster 55.

Paglia, D. E. \& W. N. Valentine: Studies on the quantitative and qualitative characterization of erythrocyte glutathione peroxidase. J. lab. clin. Med. 1967, 70, 158-169.

Peplowski, M. A., D. C. Mahan, S. A. Murray, A. L. Moxon, A. H. Cantor $\&$ K. E. Ekstrøm: Effect of dietary and injectable vitamin $\mathrm{E}$ and selenium in weaning swine antigenically challenged with sheep red blood cells. J. Anim. Sci. 1981, 51, 344-351.

Rasmussen, O. K.: Selenium concentration in sow colostrum and in sow milk. Acta Agric. Scand. 1974, 24, 175-178.

Sivertsen, T., J. T. Karlsen \& A. Fr $\phi$ slie: The relationship of erythrocyte glutathione peroxidase to blood selenium in swine. Acta vet. scand. $1977,18,494-500$.

Teige, J., S. Tollersrud, A. Lund \& H. J. Larsen: Swine dysentery: The influence of dietary vitamin $E$ and selenium on the clinical and pathological effect of Treponema hyodysenteriae infection in pigs. Res. Vet. Sci. 1982, 32, 95-100.

Øvernes, G., K. Moksnes \& A. Frøslie: Barium selenate: A long-acting selenium preparation for subcutaneous injection. Acta vet. scand. 1985, 26, 164-168. 


\section{SAMMENDRAG}

Bariumselenat som depot selenkilde til gris.

Barium selenat ble injisert intramuskulært (i.m.) eller subkutant (s.c.) på drektige purker $(0.5-1.0 \mathrm{mg}$ Se som bariumselenat $/ \mathrm{kg}$ kroppsvekt). Sammen med kontrolldyr ble disse fôret med Svinefôr 3. Det ble ikke observert noen forandringer i blodverdiene verken for selen eller glutation peroksydase (GSH-Px) aktivitet. Imidlertid ble det registrert en signifikant forskjell for disse parametrene mellom grisunger f $\varnothing \mathrm{dt}$ av behandlete og ubehandlete purker. Denne forskjellen ble opprettholdt gjennom hele sugeperioden. I et annet fors $\varnothing \mathbf{k}$ ble 20-kilos griser injisert enten s.c. eller i.m. med barium selenat (2.5 $\mathrm{mg} \mathrm{Se} / \mathrm{kg}$ kroppsvekt). Disse grisene sammen med kontrolldyr ble i fors $\varnothing$ ket gitt et spesiallaget selenfattig fôr. De behandlete grisene opprettholdt sine blodverdier av selen og GSH-Px aktivitet. Grisene som ble behandlet i.m. fikk imidlertid en nedgang i blodselen 4 uker etter injeksjonen. Ved slakting var seleninnholdet i lever og nyrer likt mellom de behandlete gruppene. Kontrollgruppen viste en meget raskt nedgang både i blodselen og GSH-Px aktivitet.

(Received June 6, 1986).

Reprints may be requested from: Edgar Brun, the Department of Animal Husbandry and Genetics, Norwegian College of Veterinary Medicine, P. O. Box 8146 Dep., N-0033 Oslo 1, Norway. 